\title{
Sarah Baudelle-Michels, Les avatars d'une chanson de geste. De Renaut de Montauban aux Quatre Fils Aymon
}

\section{G. Matteo Roccati}

\section{(2) OpenEdition}

\section{Journals}

Édition électronique

URL : http://journals.openedition.org/studifrancesi/27152

DOI : $10.4000 /$ studifrancesi.27152

ISSN : 2427-5856

Éditeur

Rosenberg \& Sellier

\section{Édition imprimée}

Date de publication : 31 décembre 2006

Pagination : 572

ISSN : 0039-2944

\section{Référence électronique}

G. Matteo Roccati, «Sarah Baudelle-Michels, Les avatars d'une chanson de geste. De Renaut de Montauban aux Quatre Fils Aymon », Studi Francesi [En ligne], 150 (L | III) | 2006, mis en ligne le 30 novembre 2015, consulté le 08 novembre 2020. URL : http://journals.openedition.org/studifrancesi/ 27152 ; DOI : https://doi.org/10.4000/studifrancesi.27152

Ce document a été généré automatiquement le 8 novembre 2020.

\section{(c) $($ ) $\odot$ (8)}

Studi Francesi è distribuita con Licenza Creative Commons Attribuzione - Non commerciale - Non opere derivate 4.0 Internazionale. 


\title{
Sarah Baudelle-Michels, Les avatars d'une chanson de geste. De Renaut de Montauban aux Quatre Fils Aymon
}

\author{
G. Matteo Roccati
}

\section{RÉFÉRENCE}

SARAH BAUDELLE-MICHELS, Les avatars d'une chanson de geste. De Renaut de Montauban aux Quatre Fils Aymon, Paris, Honoré Champion éditeur («Nouvelle bibliothèque du Moyen Age», 76), 2006, pp. 536.

1 La matière issue du Renaut de Montauban est extrêmement riche: la chanson de geste a connu nombre de développements et réécritures, d'abord au sein de la tradition épique, ensuite à travers les mises en prose et les impressions jusqu'à la littérature de colportage et aux reprises modernes, sans même tenir compte des légendes folkloriques. Face à un tel foisonnement l'A. a pris le parti de s'en tenir «à une approche littéraire des réécritures imprimées de Renaut de Montauban, de façon à porter une attention toute particulière aux remodelages de l'action et aux transpositions thématiques et stylistiques» (p. 11). L'inventaire de ces éditions est constitué de quelques deux cent titres, s'échelonnant $d u X V^{e}$ au $X X^{e}$ siècle; il comprend aussi les adaptations théâtrales, mais non les livrets d'opéra et les textes appartenant aux réélaborations européennes, notamment en Italie, dont le Roland furieux de l'Arioste et les œuvres qui s'en inspirent. A partir de cet inventaire, l'A. a retenu comme corpus de travail une vingtaine de textes, depuis l'édition princeps (1485) jusqu'au milieu du XX siècle.

2 L'introduction retrace dans ses grandes lignes l'histoire du texte, définit le corpus de travail et situe la démarche critique dans le sillage de l'approche de H. R. Jauss. Le corps de l'étude est consacré aux cadres et structures (titres, textes liminaires, modifications de structure des versions romanesques), à la thématique fondamentale de la rébellion 
(la scène de la querelle aux échecs, la figure de Charlemagne, la grandeur de l'insoumission), aux auxiliaires et décors (les personnages féminins, le cheval Bayard, les Ardennes). La conclusion dégage les lignes de force de l'analyse littéraire en essayant de cerner les modalités et facteurs d'évolution du texte primitif, les éléments de stabilité du récit originel, les causes possibles du succès de librairie. Le volume est complété par la bibliographie, les index nominum, rerum, des œuvres, des lieux. 